ELORE (ISSN 1456-3010), vol. $16-2 / 2009$.

Julkaisija: Suomen Kansantietouden Tutkijain Seura ry.

[http://www.elore.fi/arkisto/2_09/kirjallisuus_fingerroos2_2_09.pdf]

\title{
KIRJA-ARVIO:
}

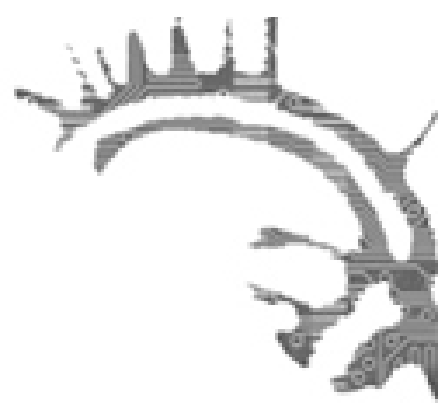

\section{KIRJa PÄIVÄnPoltTavasta AIHEESTA}

Lempiänen, Kirsti \& Löytty, Olli \& Kinnunen, Marja (toim.): Tutkijan kirja. Tampere: Vastapaino 2008. 292 sivua.

\section{$\underline{\text { Outi Fingerroos }}$}

Vastapainon kustantama Tutkijan kirja on suunnattu yhteiskuntatieteitä ja humanistisia tieteitä edustaville tutkijoille, opiskelijoille ja tutkimustyön käytänteistä kiinnostuneille. Kirjan 26 artikkelissa, joita on kirjoittanut yhteensä 31 akateemiseen maailmaan eri tavoin sijoittuvaa henkilöä, kuuluu kunkin tekijän oma ääni. Itse nimittäisinkin tekstejä akateemisiksi kokemuskertomuksiksi tutkijana olemisesta. Näkökulmina Tutkijan kirjassa ovat olosuhteet, toimijuus ja lupaukset.

\section{Olosuhteet}

Tutkijan kirjan toimittajat Kirsti Lempiäinen, Olli Löytty ja Marja Kinnunen kirjoittavat heti esipuheensa ensimmäisessä lauseessa, että tutkijalle on tarjolla monia rooleja yhteiskunnassa. Näihin rooleihin kirjan ensimmäinen osio Olosubteet paneutuu ensisijaisesti. Olosubteiden 12 artikkelissa käsitellään niin tutkimuksenteon puitteita (rahoitus, ehdot, ohjaus), odotuksia ja kansainvälisyyttä kuin tutkijana elämistä ja arkeakin.

Luvun aloittaa Eeva Peltosen essee siitä, millaisia ajatuksia professorin päässä kenties eri vuorokaudenaikoina vilisee, kun tutkimustakin pitäisi jossain välissä tehdä. Matti Hyvärinen kirjoittaa niin ikään akateemisista rytmeistä. Hän esittää joukon paradokseja, joita työ virassa sisältää: intensiivisyyden, rutiinin, stressin ja ajan riittämisen. Tosiasiahan on, että intensiivisyys - ollakseen hyödyllistä - vaatii rytminvaihdoksia, rutiineja kannattaa rikkoa stressinkin vuoksi ja aika on peruste asioiden eri tavoin tekemiselle. Oili-Helena Ylijoen artikkeli "Tutkimus yhteiskunnassa” täydentää Peltosen ja Hyvärisen käynnistämää keskustelua kiireestä ja tehokkuudesta. Rahoitus on tiedepolitiikan tärkein väline, mikä on johtanut järjettömään akateemiseen kapitalismiin. Yliopistot, yritykset ja valtion tutkimuslaitokset ovat kuin kolmoiskierre ja hybridi, joissa eri sektoreiden, perustutkimuksen, soveltavan tutkimuksen ja tuotekehittelyn rajat sumenevat. 


\section{OUtI FingerRoOS}

Erittäin tärkeä puheenvuoro suoraan tutkijankammiosta on Merja Kinnusen "Mitattu, laskettu ja punnittu tutkijan työ”. Kinnunen kysyy, mikä yhdistää yliopistojen 1600 tunnin työsuunnitelmaa, työajankohdentamisjärjestelmää, KOTA-tietokantaa, tutkimuksen ja opetuksen arviointi- ja laatujärjestelmää sekä valtion palkkausjärjestelmää syksyllä 2008? Yksittäinen tutkija vastaa mitä suurimmalla todennäköisyydellä, että kyse on aikaa vievistä riesoista, jotka ovat osa standardoitua ja koodattua yliopistoa. Kinnunen esittää, miten merkittäviä ongelmia esimerkiksi kokonaistyöajan kohdentamiseen ja KOTA-raporttien tekoon liittyy. Järjestelmät kannustavat laskelmoimaan, mistä saa maksimaalista hyötyä. Monografian kirjoittaminen ei enää kannata, tehokkuuden huippu nimittäin on nopeatahtinen artikkeliväitöskirja.

Tutkijan kirjan ensimmäisen jakso päättyy akateemista pätkätyöläisyyttä, tutkimuksen kansainvälisyyttä ja tutkijantyön käytäntöjä käsitteleviin artikkeleihin. Etenkin Rosa Meriläisen kirjoittaman "Tutkimukset poliittisessa päätöksenteossa" sisältö on paikoin poleeminen: koneisto kaipaa ihmisiä, jotka uskaltavat kutsua itseään asiantuntijoiksi. Tutkija, joka haluaa toimijaksi ja toiminnastaan rahaa, joutuu jopa valitsemaan lobbarin, aktivistin ja puoluepoliitikon roolin. "Omimmillaan lienee sellainen portfoliosukupolven rohkelikko, joka kymmenen opintopisteen kokonaisuuden suoritettuaan osaa kutsua itseään asiantuntijaksi (s. 133)."

\section{TOIMIJUUS JA LUPAUKSET}

Tutkijan kirjan toinen osa keskittyy tutkijuuteen toimintana. Artikkeleita osiossa on 12 kappaletta, mikä on mielestäni aivan liikaa. Tieteen konkreettisen tekemisen alueille sijoittuvat kirjoitukset ovat toki kiinnostavia puheenvuoroja, mutta kirjan punainen lanka - joka mielestäni on tutkimustyön tarkastelu yhteiskunnallisena toimintana - katoaa useissa teksteissä kokonaan. Toki voi ajatella, että osion tarkoituksena on esitellä juuri sellaisia tutkimuksenteon käytänteitä, joihin törmäämme kulkiessamme tutkijankammioista toiseen suomalaisissa yliopistoissa.

Kokoelma päättyy lupauksiin eli keskusteluihin siitä, mitä sellaista tutkimuksenteko tarjoaa, että tutkijaksi kannattaa ryhtyä. Artikkeleita lopetusluvussa on kaksi, ja molemmissa palataan humanistisen ja yhteiskuntatieteellisen tutkimuksen ytimeen: yliopistoissa tehtävää tutkimusta tulisi paljon nykyistä kiihkeämmin puolustaa kiireeltä ja kilpailulta. Kirsti Lempiäinen ja Päivi Mehtonen käyvät artikkelissaan "Tutkimuksen lupaukset" vuoropuhelua keskiaikaisen utopiakirjailijan Christina de Pisan Naisten kaupungin (alkup. Le livre de la cité des dames, 1405) ja feministisosiologi Charlotte Perkins Gilmanin Naistenmaan (alkup. Herland, 1915) kanssa. Teokset inspiroivat artikkelin kirjoittajia tarkastelemaan tutkimusta toimintana ja kuvitteluna, kuten myös sattumana, utopiana ja leikkinä. Tutkijan kirjaan Gilmanin toteamat sopivat erinomaisesti, sillä tutkimuksenteolle tärkeintä ei ole suoriutuminen kiireessä ja rutiininomaisesti työhuoneissamme. Sen sijaan tutkijan tulisi ottaa itselleen aikaa ja mennä johonkin "utopiapajaan" ideoimaan - jopa manifestoida radikaalisti toimintansa oikeutusta, kuten Lempiäinen ja Mehtonen (s. 272) tekevät: 
- Hengen vallankumous! (Oikeus ajatella.)

- Määrän vallankumous! (Tehtäköön mieluummin yksi asia hyvin kuin kymmenen huonosti.)

- Laadun vallankumous! (Laatu on sisäistä sivistystä ja kunnianhimoa eikä tee itsestään numeroa.)

Mainio on myös Eeva Peltosen puheenvuoro hitaasta tutkimuksesta (engl. slow research), tällaiselle liikkeelle nimittäin "taitaisi olla tarvetta ja tilausta". Kirjoituksen inspiraatio on peräisin1980-luvun Slow food-liikkeestä, joka puolusti hidasta ruokaa, jota valmistetaan aikaa ja vaivaa säästämättä ilman tehoviljelyä ja geenimanipulaatiota. Peltonen esittää kolmen nimekkään ja akateemisella urallaan jo pitkälle ehtineen tutkijan tähänastiset pääteokset: Risto Alapuron Suomen synty paikallisena ilmiönä 1890-1933 (1994), Ulla-Maija Peltosen Punakapinan muistot (1996) ja Armas Niemisen Taistelu sukupuolimoraalista I. (1993). Nämä monografiat joko antoivat odottaa itseään, ehtivät olla useammassakin vaiheessa tai jäivät ensimmäiseen osaan. Ne ovat esimerkkejä hitaasta, kenties nykyään jo nostalgisesta tutkimuksen tekemisen tavasta, mutta myös merkittäviä tutkimuksia, koska ne jäivät tuleville tutkijapolville perinnöksi ja puhuttelivat muitakin kuin tiedepiirejä. Hidas tutkimus -liikkeen tulisikin rohkaista tutkijoita yksilöllisiin elämäntapamuutoksiin, jotta tutkimuksen laatu säilyisi. "Tärkeää olisi sellaisten rakenteiden ja järjestelyjen kyseenalaistaminen, jotka ovat vaarantaneet tutkijoiden edellytykset syventyä lukemaan, tutkimaan, ajattelemaan ja keskustelemaan (s. 285)."

\section{YHTEENVETO}

Kirjan toimittaneet Kirsti Lempiäinen, Olli Löytty ja Marja Kinnunen ovat halunneet tehdä kirjan tutkijan työstä, "joka tuntuu hukkuvan jatkuvien rakenteellisten uudistusten, laadun parantamisen ja vaikuttavuuden alle. Vaikka tutkimuksen merkitystä korostetaan monissa juhlapuheissa ja tutkimuslaitosten strategioissa, tutkijoiden rauhaa ja työnteon mahdollisuuksia ei tarpeeksi puolusteta. Tutkijan kirja arvostaa tutkijoita ja tutkimusta. (s. 8-9)" Tässä tehtävässä toimittajat ovat onnistuneet lähes erinomaisesti. Mielestäni Tutkijan kirja on herkullista luettavaa niiltä osin, kun se pysyy teemassaan eli tutkijuudessa yhteiskunnassa. Artikkelien runsaus tekee kokonaisuudesta laajan. Itse näen, että Tutkijan kirjasta olisi tiivistetyssä muodossa ollut ainesta jopa pamfletiksi eli arvostelevaksi kirjaseksi päivänpolttavasta aiheesta. 
Outi FingerRoOS

\section{KIRJALlisuUS}

ALAPURO, RISTO 1994: Suomen synty paikallisena ilmiönä 1890-1933. Helsinki: Hanki ja jää.

NIEMINEN, ARMAS 1951: Taistelu sukupuolimoraalista I. Avioliitto- ja seksuaalikysymykesiä suomalaisen hengenelämän ja yhteiskunnan murroksessa sääty-ybteiskunnan ajoilta 1910-luvulle. Porvoo: WSOY.

PELTONEN, ULLA-MAIJA 1996: Punakapinan muistot. Tutkimus työväen muistelukerronnan muotoutumisesta vuoden 1918 jälkeen. Helsinki: SKS.

Dosentti Outi Fingerroos työskentelee etnologian yliassistenttina Jyväskylän yliopistossa. 